\title{
INTRODUCING A POWER OF THE OPERATOR IN DIRECT SPECTRAL PROBLEMS
}

\author{
G.A. Zakirova, South Ural State University, Chelyabinsk, Russian Federation, \\ zakirova81@mail.ru, \\ E. V. Kirillov, South Ural State University, Chelyabinsk, Russian Federation, \\ thefallk@mail.ru
}

The resolvent method, proposed by Sadovnichiy and Dubrovsky in the 1990s, is successfully applied in the direct spectral problem to calculate the asymptotics of eigenvalues of the perturbed operator, find formulas for the regularized trace, and recover perturbation. But the application of this method faces difficulties when the resolvent of the unperturbed operator is non-nuclear. Therefore, a number of physical problems could only be considered on the interval. This article describes a justification of the transition to the power of an operator in order to expand the area of possible applications of the resolvent method. Considering the problem of calculating the regularized trace of the Laplace operator on a parallelepiped of arbitrary dimension, we show that for every fixed dimension it is possible to choose the required power of the operator and to calculate the regularized traces. These studies are relevant due to the need to study important applied problems, particularly in hydrodynamics, electronics, elasticity theory, quantum mechanics, and other fields.

Keywords: regularized trace; Laplace operator; power of operator.

\section{Introduction}

Even though the spectral theory of operators began in the nineteenth century, it is still actively developing. It includes separate directions like the problem of computing regularized trace, inverse problems, the calculation of spectral characteristics. This work, representing the school of Sadovnichiy and Dubrovsky, is devoted to the calculation of the regularized trace of the Laplace operator on a parallelepiped of arbitrary dimension. The problem of finding the regularized trace, besides its mathematical significance, has physical meaning. For example, the formula for the regularized trace of the Sturm-Liouville equation describes energy conservation in the dynamical system described by the Korteweg-de Vries equation [1]. With the aid of regularized traces calculated by Liphshic [2], a modification of the free energy of a crystal with implemented admixtures was found.

The theory of regularized traces originated with the work of Gelfand and Levitan (1953) [3], who found the asymptotics of the eigenvalues of the Sturm-Liouville operator. In the 1960s Lidskii and Sadovnichiy almost completed this theory for ordinary differential operators. They succeeded in calculating the regularized traces of boundary value problems for ordinary differential equations of arbitrary order with a complex occurrence of the parameter. Partial differential operators are much more difficult to study. Kostyuchenko and Gasimov [4], as well as other authors, obtained various results in this direction. The challenge is that for partial differential equations the resolvent has special structure, and the exact asymptotics of the eigenvalues is unknown. Sadovnichiy and Dubrovsky proposed 
the so-called resolvent method, which enabled them to avoid these difficulties using perturbative corrections. Subsequently, basing on this method, the followers of Dubrovsky obtained a regularized trace formula for the Laplace operator [5] or a Chebyshev-type operator [6] and investigated the existence and uniqueness [7] of the perturbing operator and the stability of the solution [8]. They proposed algorithms for reconstructing the potential for models with the Laplace operator [9]. The approach of these studies rests on the principle of lowering the power of the operator, as the Laplace operator itself is widely applied in physics rather than its powers. This paper presents a fundamentally different approach: we regard the power of an operator as an opportunity to explore physical problems not only on the interval, but also in other dimensions.

\section{The Regularized Trace}

Take the $N$-dimensional parallelepiped

$$
\Pi=\left\{x=\left(x_{1}, x_{2}, \ldots, x_{N}\right): 0 \leq x_{j} \leq a_{j}, j=1, \ldots, N\right\},
$$

where $a_{j}>0$. Denote by $\mathcal{U}$ a separable Hilbert space with the inner product

$$
(f, h)=\int_{\Pi} f(x) h(x) d x
$$

and the norm $\|h\|=\sqrt{(h, h)}$. In the space $\mathcal{L}(\mathcal{U})$ consider the discrete selfadjoint operator $T$ of the Dirichlet boundary value problem

$$
-T v=\lambda v,\left.\quad v\right|_{\partial \Pi}=0 .
$$

By a discrete operator we understand an operator whose spectrum is discrete. Assume that the eigenvalues $\lambda_{m} \in \mathbf{R}$ of $T$, for $m=\left(m_{1}, m_{2}, \ldots, m_{N}\right)$, in the ascending order, have the asymptotics $\lambda_{k} \sim C k^{\frac{2 \beta}{N}}$ with $\beta \geq 1$ and $C=$ const. For example, consider the Dirichlet boundary value problem for the Laplace operator on the rectangle. Obviously, the eigenvalues in this case satisfy the asymptotics. [10]

Next, given a bounded operator $P$ defined everywhere on $\mathcal{U}$, we can show that $T+P$ is a discrete operator. Denote by $\mu_{k}$ its eigenvalues in the ascending order of their real parts.

Lemma 1. Take a discrete selfadjoint operator $T \in \mathcal{L}(\mathcal{U})$. If the perturbing operator $P$ satisfies $\|P\|<r / 2$, where $0<r \leq r_{0}=\inf _{k} r_{k}$ with $r_{k}=\frac{1}{2} \min \left\{\lambda_{k+1}-\lambda_{k} ; \lambda_{k}-\lambda_{k-1}\right\}$ for $k>1$ and $r_{1}=\frac{1}{2}\left(\lambda_{2}-\lambda_{1}\right)$, then $T+P$ is discrete and the following claims hold:

(i) if $R_{0}(\lambda) \in S / q$ then $R(\lambda) \in S / q$ for $1 \leq q<\infty$;

(ii) if $\lambda_{k} \in C \backslash \Omega_{r_{k}}$ then $\mu_{k}^{s} \in C \backslash \Omega_{r_{k}}$ for $s=\overline{1, \nu_{k}}$, and $\nu_{k}$ is the multiplicity of the eigenvalue $\lambda_{k}$.

Therefore, the multiplicities of the eigenvalues of $T$ and $T+P$ lying in the circle $\gamma_{r_{k}}$ are equal.

Let us put the problem of finding the numbers $A_{k}$ so that the series

$$
\sum_{k}\left(\mu_{k}-\lambda_{k}-A_{k}\right)
$$


converges and determining the sum of the series. This series is called the regularized trace of the operator $T+P$.

As we can see from the asymptotics, for all $N \geq 2$ the series

$$
\sum_{t=0}^{\infty} \frac{1}{\lambda_{t}}
$$

diverges. Therefore, we cannot apply the resolvent method when $N>2$. To resolve this difficulty and treat arbitrary dimension, we introduce a new boundary value problem with the power $T^{\beta}$ of $T$ :

$$
\left(-T^{\beta}+P\right) v=\lambda v,\left.\quad v\right|_{\partial \Pi}=0 .
$$

The eigenfunctions of these problems coincide, but the eigenvalues of $T^{\beta}$ are equal to $\lambda_{k}^{\beta}$. The asymptotics of the eigenvalues of the new operator shows that it is possible to consider the problem in arbitrary dimension when a suitable $k$ is found.

Assume that the suitable $k$ is found. Following[9], we obtain

Theorem 1. If $\beta>N / 2$ and $\|P\|<r / 2$, where $0<r \leq r_{0}$, then for all $k \in \mathbb{N}$ we have

$$
\sum_{s=1}^{\nu_{k}} \mu_{k}^{s}=\nu_{k} \lambda_{k}^{\beta}-\sum_{s=1}^{\nu_{k}}\left(P v_{k}^{s}, v_{k}^{s}\right)+\alpha_{k}(p),
$$

where

$$
\alpha_{k}(p)=\frac{1}{2 \pi i} \int_{\gamma_{r_{k}}} \lambda \operatorname{Tr}\left[R(\lambda)\left(P R_{0}(\lambda)\right)^{2}\right] d \lambda .
$$

Evaluating perturbative corrections, we see that they vanish for all $n>2$. Thus, we obtain

Theorem 2. If $\beta>N / 2$ and $\|P\|<r / 2$, where $0<r \leq r_{0}$, then for all $k \in \mathbb{N}$ we have the regularized trace formula

$$
\sum_{s=1}^{\nu_{k}} \mu_{k}^{s}=\nu_{k} \lambda_{k}^{\beta}-\sum_{s=1}^{\nu_{k}}\left(P v_{k}^{s}, v_{k}^{s}\right) .
$$

\section{References}

1. Zakharov V.E., Faddeev L.D. Korteweg-de Vries Equation: A Completely Integrable Hamiltonian System. Functional Analysis and its Applications, 1971, vol. 5, no. 4, pp. 280-287. DOI: 10.1007/BF01086739

2. Lifshits I.M. [On a Problem of Perturbation Theory Connected with Quantum Statistics]. Uspekhi matematicheskikh nauk [Russian Mathematical Surveys], 1952, vol. 7 , no. 1, pp. 171-180. (in Russian)

3. Gel'fand I.M., Levitan B.M. [An Identity for the Eigenvalues of Second Order Differential Operator]. Doklady Akademii Nauk SSSR, 1991, vol. 84, no. 4, pp. 593-596. (in Russian)

4. Levitan B.M., Gasymov M.G. [Determination of a Differential Equation by two of its Spectra]. Russian Mathematical Surveys, 1964, vol. 19, no. 2, pp. 1-63. DOI: 10.1070/RM1964v019n02ABEH001145. 
5. Torshina O.A. [The Formula for the First Regularized Trace for the Laplace-Beltrami Operator with Nonsmooth Potential in the Projective Plane]. Differentsial'nye uravneniya i ikh prilozheniya [Differential Equations and Their Applications], Samara, 2006, pp. 32-40. (in Russian)

6. Zakirova G.A., Sedov A.I. [Asymptotics of the Eigenvalues of the Chebyshev Type Operator with Complex Occurrence of the Parameter]. Vestnik Magnitogorskogo gosudarstvennogo universiteta [Bulletin of Magnitogorsk State University], 2004, issue 6, pp. 65-73. (in Russian)

7. Sedov A.I. [On the Existence of Solutions of the Inverse Problem of Spectral Analysis for Self-adjoint Operator in a Hilbert Space]. Obozrenie prikladnoy i promyshlennoy matematiki [Review of Applied and Industrial Mathematics], 2010, vol. 17, issue 3, pp. 454-455. (in Russian)

8. Dubrovskiy V.V., Nagornyy A.V. [ Stability of the Solution of Inverse Problems]. Differentsial'nyy uravneniya [Differential Equations], 1992, vol. 28, no. 5, pp. 839-843. (in Russian)

9. Zakirova G.A. Obratnye spektral'nye zadachi dlya operatora Laplasa s kratnym spektrom. Priblizhennoe vosstanovlenie potentsiala [Inverse Spectral Problem for the Laplace Operator with Multiple Spectrum. Approximate Recovery Potential]. Saarbrücken, LAPLAMBERTAcademicPublishing, 2011. (in Russian)

10. Titchmarsh E.C. Eigenfunction Expansion Associated with Second Order Differential Equations. Oxford At The Clarendon Press, 1961.

Received May 16, 2014

\title{
ВВЕДЕНИЕ СТЕПЕНИ ОПЕРАТОРА ПРИ РЕШЕНИИ ПРЯМЫХ СПЕКТРАЛЬНЫХ ЗАДАЧ
}

\author{
Г.А. Закирова, Е.В. Кириллов
}

\begin{abstract}
Резольвентный метод, предложенный еще в 90-х гг В.А. Садовничим и В.В. Дубровским, с успехом применим как в прямых спектральных задачах при вычислении асимптотики собственных чисел возмущенного оператора или формул регуляризованных следов, так и в обратных - при восстановлении потенциала. Однако, применение этого метода вызывает затруднения в тех случаях, когда резольвента невозмущенного оператора оказывается неядерной. Поэтому ряд физических задач, как известно, приходится рассматривать только на интервале. В данной работе приведено обоснование перехода к степени оператора для расширения области применения резольвентного метода. Рассмотрен вопрос о вычислении регуляризованного следа оператора Лапласа на параллелепипеде произвольной размерности. Показано, что для любой фиксированной размерности возможно подобрать нужную степень оператора и вычислить регуляризованный след. Актуальность этих исследований обусловлена необходимостью изучения важных прикладных задач, в частности, в области гидродинамики, радиоэлектроники, теории упругости, квантовой механики и других.

Ключевые слова: регуляризованный след; оператор Лапласа.
\end{abstract}




\section{Литература}

1. Захаров, В.Е. Уравнение Кортевега-де Фриза - вполне интегрируемая гамильтонова система / В.Е. Захаров, Л.Д. Фаддеев //Функциональный анализ и его приложения. - 1971. - Т. 5, вып. 8. - С. 18-27.

2. Лифшиц, И.М. Об одной задаче теории возмущений, связанной с квантовой статистикой / И.М. Лифшиц // Успехи математических наук. - 1952. - Т. 7, вып. 1. - C. $171-180$.

3. Гельфанд, И.М. Об одном тождестве для собственных значений дифференциального оператора второго порядка / И.М. Гельфанд, Б.М. Левитан // ДАН СССР. - 1991. - T. 84, №4. - C. 593-596.

4. Гасымов, М.Г. Определение дифференциального оператора по двум спектрам / М.Г. Гасымов, Б.М. Левитан // Успехи математических наук. - 1964. - Т.19, №2 . - C. 3-63.

5. Торшина, О.А. Формула первого регуляризованного следа оператора ЛапласаБельтрами с негладким потенциалом на проективной плоскости / О.А. Торшина // Дифференциальные уравнения и их приложения. - Самара, 2006. - С. 32-40.

6. Закирова, Г.А. Асимптотика собственных чисел степени оператора Чебышева I рода со сложным вхождением параметра / Г.А. Закирова, А.И. Седов // Вестник МаГУ. - 2004. - Вып. 6. - С. 65-73.

7. Седов, А.И. О существовании решения обратной задачи спектрального анализа для самосопряженного оператора в гильбертовом пространстве / А.И. Седов // Обозрение прикладной и промышленной математики. - 2010. - Т. 17, вып. 3. C. $454-455$.

8. Дубровский, В.В. Устойчивость решения обратных задач / В.В. Дубровский, А.В. Нагорный // Дифференциальные уравнения. - 1992. - Т. 28, № 5. C. 839-843.

9. Закирова, Г.А. Обратные спектральные задачи для оператора Лапласа с кратным спектром. Приближенное восстановление потенциала / Г.А. Закирова. Saarbrücken: LAPLAMBERTAcademicPublishing, 2011.

10. Титчмарш, Э.Ч. Разложение по собственным функциям, связанные с дифференциальными уравнениями второго порядка / Э.Ч. Титчмарш. - М.: Изд-во иностр. лит., 1961.

Галия Амрулловна Закирова, кандидат физико-математических наук, доцент, кафедра «Уравнения математической физики», Южно-Уральский государственный университет (г. Челябинск, Российская Федерация), zakirova81@mail.ru.

Евгений Вадимович Кириллов, магистрант, кафедра «Уравнения математической физики», Южно-Уральский государственный университет (г. Челябинск, Российская Федерация), thefallk@mail.ru.

Поступила в редакиию 16 мая 2014 г. 